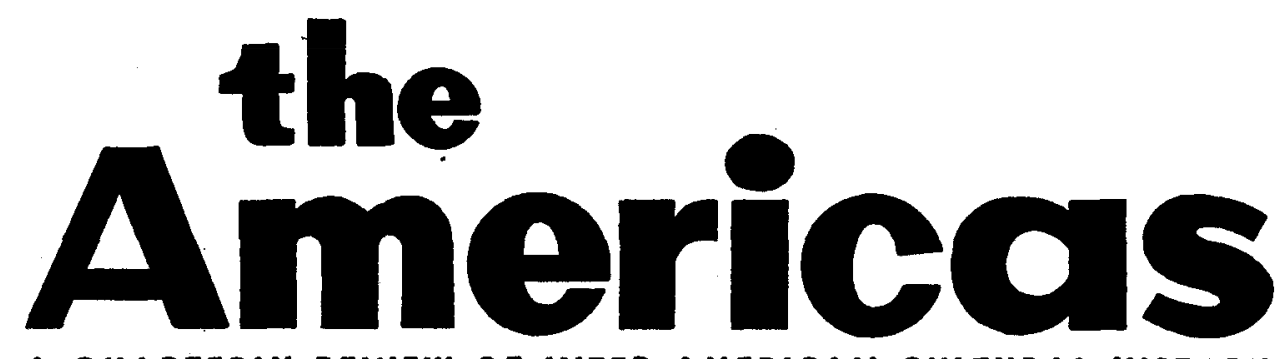

A QUARTERLY REVIEW OF INTER-AMERICAN CULTURAL HISTORY

\title{
VOLUME XIII
}

\section{JULY, 1956, THROUGH APRIL, 1957}

Published Quarterly

$$
\text { by the }
$$

Academy of American Franciscan History

Washington, D. C. 


\section{ARTICLES}

Frenchmen and Francophiles in New Spain from 1760 to

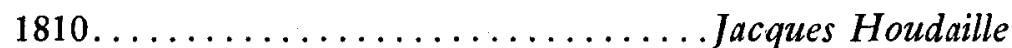

British Honduras: From Public Meeting to Crown Colony Herbert F. Curry

Land Tenure Among the Aborigines of Latin America

Sam Scbulman

The Relation Between the Noticias Secretas and the Viaje a la America Meridional................ Luis Merino

Irvíng's Columbus: A Problem of Romantic Biography

William L. Hedges

Some Franciscan Sources in the Archives and Libraries of America ....................... Lino G. Canedo

Omer Englebert's The Last of the Conguistadores, Junípero Serra....................Eric O'Brien

Some Ideological Aspects of the Conquest of the

Philippines..................Jobn Leddy Phelan

Gabino Gainza and Central America's Independence

From Spain..................... Gordon Kenyon

Religious Aspects of Symbolic Acts of Sovereignty

Manuel Servin 255

Tehuacán-Franciscan Outpost............Fanchón Royer 269

Indian Congregations in the New Kingdom of Granada: Land

Tenure Aspects, 1595-1850......... Orlando Fals-Borda 331

Thoughts on Church Architecture in Mexico

Gordon Bodenwein 353

Public Work and Soctal Welfare in Colonial Spanish

American Towns.................Fredrick B. Pike 361

The Franciscan Province of the Holy Cross of Española, 1505-1559...................ntonine S. Tibesar 


\section{DOCUMENTS}

The Mission of São Miguel de Una in Pernambuco, Brazil

(Ed.) Venâncio Willeke 69

A Plan for Convict Colonies in Canada

(Ed.) Richard H. Dillon 187

"Dr. Atr" and Venustiano Carranza

(Ed.) Cbarles E. Cumberland 287

Constitutions of the Franciscan Province of the Holy Cross

in Española (1538-1540).......(Ed.) Antonine S. Tibesar 391

\section{NOTES AND REVIEWS}

Inter-American Notes................

Book Reviews and Notes..............81, 205, 303, 406 